\title{
Occurrence of Indole-3-Acetic Acid-Producing Bacteria on Pear Trees and Their Association with Fruit Russet
}

\author{
Steven E. Lindow, Caroline Desurmont, Rachel Elkins, Glenn McGourty, Ellen Clark, and Maria T. Brandl
}

\begin{abstract}
First, second, fifth, and sixth authors: Department of Plant and Microbial Biology, University of California, Berkeley 94720-3201; third author: University of California, Cooperative Extension, Lake County, 883 Lakeport Blvd., Lakeport 95453; and fourth author: University of California, Cooperative Extension, Mendocino County, 579 Low Gap Road, Ukiah 95482.
\end{abstract}

Current address of E. Clark: California Department of Justice, 626 Bancroft Way, Berkeley 94710.

Accepted for publication 2 July 1998.

\begin{abstract}
Lindow, S. E., Desurmont, C., Elkins, R., McGourty, G., Clark, E., and Brandl, M. T. 1998. Occurrence of indole-3-acetic acid-producing bacteria on pear trees and their association with fruit russet. Phytopathology 88:1149-1157.

A relatively high percentage of epiphytic bacteria on pear leaf and fruit surfaces had the ability to produce indole-3-acetic acid (IAA) in culture media supplemented with tryptophan. While over $50 \%$ of the strains produced at least small amounts of IAA in culture, about $25 \%$ of the strains exhibited high IAA production as evidenced by both colorimetric and highperformance liquid chromatography analysis of culture supernatants. A majority of the strains that produced high amounts of IAA were identified as Erwinia herbicola (Pantoea agglomerans), while some strains of Pseu-

in 39 out of 46 trials over an 8-year period in which IAA-producing bacteria were applied to trees compared with control trees. A linear relationship was observed between fruit russet severity and the logarithm of the population size of different IAA-producing bacteria on trees in the 30 days after inoculation, when normalized for the amount of IAA produced by each strain in culture. On average, the severity of fruit russet was only about $77 \%$ that on control trees when trees were treated at the time of bloom with Pseudomonas fluorescens strain A506, which does not produce IAA. Both total bacterial populations on pear in the 30-day period following full bloom and fruit russet severity varied greatly from year to year and in different commercial orchards over a 10-year period. There was a strong linear correlation between the logarithm of total bacterial population sizes and fruit russet severity.
\end{abstract} domonas syringae, Pseudomonas viridiflava, Pseudomonas fluorescens, Pseudomonas putida, and Rahnella aquaticus that produced high amounts of IAA also were found on pear. Fruit russeting was significantly increased
Additional keywords: auxin, biological control, epiphytes, lenticel.
Many pome fruits including pear and apple are subject to a condition known as fruit russet. Areas on the surface of russetted fruit, particularly in the vicinity of lenticels on pear fruit, appear brown and corky at maturity. This phenomenon is one of the most important horticultural problems encountered in the production of pear and apple worldwide. Many millions of dollars was lost annually when fruits that normally have a smooth appearance become russetted $(11,38)$. Russetted fruit is not only unappealing to consumers, but also has a reduced storage life (38). Russet results from damage to epidermal cells that occurs within the first 30 to 40 days after petal fall. It is during this time that the epidermal cells of fruit are undergoing their most rapid rate of cell division and enlargement, apparently predisposing them to chemical and environmental stresses $(3,7,11)$. Once the epidermal cells are damaged, a brown layer of suberized cells forms in the lower epidermal region $(3,7)$. As cork cells develop, they push outward and become exposed to the surface of the fruit as the fruit matures and the cuticle sloughs off $(3,7)$. For this reason, fruit russet is often most apparent at harvest, even though it is apparently induced much earlier during fruit development.

The causes of fruit russet have remained elusive. Apparently, any damage to the epidermal cells of fruits, particularly early in fruit development, can induce fruit russet. Hence, some pesticides including copper compounds and adjuvants such as surfactants that are applied to trees can damage epidermal cells and induce russet (11, 38). The application of synthetic auxins such as naphthalene acetic acid (NAA) can also induce russet $(11,17,38)$. Russet is also strongly

Corresponding author: S. E. Lindow; E-mail address: icelab@socrates.berkeley.edu

Publication no. P-1998-0908-01R

(C) 1998 The American Phytopathological Society associated with the occurrence of high relative humidities or free moisture on trees during the early spring in the absence of chemical injuries to the fruit surface $(11,38)$. The effect of moisture on fruit russet has usually been assumed to be due to its effect on the turgor of epidermal cells, making them more susceptible to other environmental stresses $(11,38)$.

Several aspects of the pattern of occurrence of fruit russet suggest that it could have a microbiological cause. Moist conditions usually favor the growth of microorganisms on plants (21). Therefore, moist conditions in the spring would likely be associated both with high microbial population sizes as well as fruit russet. A variety of bacterial colonists of plant surfaces have been shown to influence plant growth. Most notably, exogenous auxin production by bacteria has been associated with altered growth of the roots of plants on which they were inoculated $(2,9,25,32)$. While many plant growth-promoting bacteria, which stimulate the growth of roots, can produce at least small amounts of the auxin indole-3-acetic acid (IAA) $(2,9,25,32)$, high IAA producers are inhibitory to root growth $(9,25,43)$. Because root elongation is inversely proportional to exogenous IAA concentrations above a threshold of about $10^{-6}$ to $10^{-9} \mathrm{M}$ (depending on the plant species) $(33,36)$, bacteria capable of producing high amounts of IAA are probably often inhibitory to the roots on which they grow $(9,25,32,43)$. As noted above, exogenous auxin has been shown to induce fruit russet when applied early in fruit development $(11,17,38)$. Hence, the epidermal cells of fruits apparently can be damaged by excessive amounts of exogenous auxin. It has also been noted that the severity of fruit russet can be reduced by the application of gibberellins $(28,38)$. Since the balance between gibberellins and auxins regulates cell development, this suggests that excess auxin may occasionally occur on the epidermis of pome fruits. Taken together, these observations indicate that 
IAA-producing bacteria may cause fruit russet by producing IAA that could disrupt the normal hormonal balance of epidermal cells.

This study was designed to test the hypothesis that IAA-producing epiphytic bacteria could induce fruit russet by altering the development of the epidermal cells of immature fruit. We, therefore, surveyed the occurrence of IAA-producing bacteria on pears and determined if altering their population size influenced the severity of fruit russet.

\section{MATERIALS AND METHODS}

Bacterial strains. The source and characteristics of Pseudomonas fluorescens strains A526 and A506 have been described previously (20,41). IAA production in Erwinia herbicola (Pantoea agglomerans) strain 299R has also been reported (4). P. fluorescens strains TS65 and 7SR7 were isolated from the rhizosphere of sugar beet and were the gift of T. Suslow and J. Loper, respectively. The other bacterial strains used to inoculate pear trees were isolated from different individual pear spurs collected from two commercial 'Bartlett' pear (Pyrus communis) orchards located near Healdsburg, CA, in April 1985. Bacterial colonies were chosen randomly from among the predominant bacteria isolated from dilution plates of spur washings onto $1 / 10$-strength Kings medium B (18) containing cycloheximide $(100 \mu \mathrm{g} / \mathrm{ml})(\mathrm{KB})$ and were purified by restreaking on KB. The identity of $P$. syringae strains $\mathrm{P} 1016$, P767, 380R, and P56; P. fluorescens strains 268R and 308R; and E. herbicola strains 276R, 299R, 240R, and 389R from these sources was confirmed by gas-chromatographic analysis of fatty acid methyl esters (GC-FAME analysis) of total lipids extracted from these strains by standard methods (35). Spontaneous rifampicin-resistant mutants of these strains for use in field inoculations were isolated as in previous studies (31). Two collections consisting of 257 and 487 bacterial strains were made as above from different individual pear spurs collected from commercial 'Bartlett' pear orchards located near Hopland, CA, in April 1990, and Ukiah, CA, in 1993, respectively, and were screened for IAA production. Colonies producing a diffusible yellow-green pigment on $\mathrm{KB}$ were tentatively identified as Pseudomonas species, while those producing a characteristic yellow color were designated $E$. herbicola.

Culture media. Surveys for IAA production were done in KB broth medium supplemented with $0.2 \mathrm{mg}$ of L-tryptophan per $\mathrm{ml}$. For quantification of IAA production via high-performance liquid chromatography (HPLC), cells were grown in minimal A medium (29) supplemented with $2.0 \mathrm{mg}$ of succinate per $\mathrm{ml}, 2.0 \mathrm{mg}$ of yeast extract per $\mathrm{ml}$, and $0.2 \mathrm{mg}$ of tryptophan per ml. Cells were inoculated at an initial concentration of about $10^{7}$ cells per ml into Erlenmeyer flasks containing $50 \mathrm{ml}$ of culture medium and incubated in the dark on a rotary shaker at $200 \mathrm{rpm}$ at $27^{\circ} \mathrm{C}$. In both cases, cultures were grown until stationary phase (usually about $48 \mathrm{~h}$ ). Estimates of total bacterial populations were made on $\mathrm{KB}$ agar plates. Rifampicin-resistant strains inoculated onto pear were recovered on $\mathrm{KB}$ containing rifampicin $(100 \mu \mathrm{g} / \mathrm{ml})$ (KBR). For inoculation of bacterial strains in small-scale field experiments, cells were scraped from the surface of KBR plates after 2 days of growth at $24^{\circ} \mathrm{C}$ and suspended in tap water. The cell suspensions were diluted with tap water to a concentration of approximately $10^{8}$ cells per $\mathrm{ml}$ as determined by turbidity. The registered biological pesticide Blightban A506 (Plant Health Technologies, Boise, ID), which is a lyophilized preparation of cells $\left(1.2 \times 10^{11}\right.$ cells per $\mathrm{g}$ ) of $P$. fluorescens strain A506 recovered from broth culture, was used in large-scale field experiments.

Measurement of IAA. (i) Colorimetric analysis. Supernatants were obtained after centrifugation of cell cultures at $10,000 \times g$ for 5 min. Two milliliters of Salkowski reagent (15) (prepared with perchloric acid) was added to $1 \mathrm{ml}$ of a culture supernatant in a small glass test tube and incubated at room temperature for $30 \mathrm{~min}$. The optical density of the solutions was quantified using a PerkinElmer Lambda 3A spectrophotometer (Perkin-Elmer Corp., Norwalk,
CT) at $530 \mathrm{~nm}$. (ii) Thin-layer chromatography (TLC). Analysis of indole compounds by TLC was performed on silica gel-covered glass plates using EIA solvent: ethylacetate/isopropanol/ammonium hydroxide (45:35:20, vol/vol). The chromatograms were developed by spraying with Ehmann's reagent (10) followed by heating at $200^{\circ}$ C. (iii) HPLC. IAA and other indole derivatives were resolved on a Perkin-Elmer series 410 HPLC (Perkin-Elmer Corp.) equipped with a Microsorb C-18 reverse-phase column (5- $\mu$ m particle size, $4.6 \mathrm{~mm} \times 35 \mathrm{~cm}$; Rainin Instrument Co., Inc., Woburn, MA) maintained at $30^{\circ} \mathrm{C}$. Eluates were detected with a variable-wavelength spectrophotometric detector operated at $280 \mathrm{~nm}$. A mobile phase of $28 \%$ methanol in $0.5 \%$ aqueous acetic acid was used under isocratic conditions and at a flow rate of $1 \mathrm{ml} / \mathrm{min}$. IAA and other indole compounds were quantified by reference to the peak area obtained for known concentrations of respective standards (Sigma Chemical Co., St. Louis).

Southern hybridizations. Blot hybridization analysis of genomic DNA of bacterial strains was performed with the Genius Kit (Boehringer Mannheim Biochemicals, Indianapolis, IN) according to the manufacturer's instructions. Digoxigenin-labeled DNA of pUB12 containing the ipdC gene from E. herbicola strain 299R (5) was used as a hybridization probe under high- and lowstringency conditions as previously described (5).

Field plot design. All field studies were conducted in commercial orchards containing mature 'Bartlett' pear trees. The orchards were in the major European pear-growing regions of California located in Lake, Mendocino, Sacramento, Solano, and Yuba counties. The trees in most orchards were separated by about $4 \mathrm{~m}$ within a row and $7 \mathrm{~m}$ between adjacent rows of trees. Most trees were about 4 to $5 \mathrm{~m}$ in height. At least two experiments were conducted in each of the 10 years of this study; a total of 28 small-scale and 12 large-scale trials were conducted. Small-scale field experiments were conducted on trees organized in a randomized complete block (RCB) design with four replications in an orchard section where no other antibiotics than those described in the experimental design were applied to the trees. Each replication consisted of one to four trees in a given row of trees, depending on the experiment; a single tree separated treated trees within a block and different blocks were in adjacent rows of pear trees. While no antibiotics or other bactericides were applied to the plot area, fungicides such as benomyl and mancozeb were applied to control pear scab caused by the fungus Venturia pyrina Aderhold.

Bacteria were applied to wetness (about 3 liters per tree) to trees at about $20 \%$ bloom using a backpack mist blower (1). Some of the trees treated with $P$. fluorescens strain A506, as well as trees not treated with this strain, in the small-scale tests were sprayed at 7-day intervals with streptomycin sulfate (Agristrep D, 21\%; Merck and Company, Inc. Rahway, NJ) at a concentration of $100 \mu \mathrm{g} / \mathrm{ml}$ or with oxytetracycline (Mycoshield, 17\%; Pfizer, Inc., New York, or Merck and Company, Inc.) at a concentration of $100 \mu \mathrm{g} / \mathrm{ml}$. In a given trial, trees were sprayed with antibiotics starting at the time that $P$. fluorescens strain A506 was applied to the trees; the antibiotics were applied to the trees within $1 \mathrm{~h}$ after the bacterium was inoculated onto the trees. Some trees also received treatments of either NAA (15 ppm) or giberellic acid GA4+7 (20 ppm). Chemicals were applied either with a backpack mist blower or with a piston-pressurized handgun sprayer (1).

Large-scale experiments also were conducted on trees organized in a RCB design with four replications; each replication of each treatment consisted of groups of 25 to 200 trees, at least five rows wide and having at least five trees within a row. All the trees in the large-scale tests were sprayed with solutions of streptomycin sulfate $(100 \mu \mathrm{g} / \mathrm{ml})$ or oxytetracycline $(100 \mu \mathrm{g} / \mathrm{ml})$ by cooperating growers using commercial air-blast sprayers. Bactericides were sprayed at intervals that the cooperators determined, generally at 3- to 7-day intervals depending on prevailing weather conditions. Lyophilized preparations of $P$. fluorescens strain A506 were dispersed into tap water in either a commercial air-blast sprayer or a 
piston-pressurized handgun sprayer at a concentration of $10^{8}$ cells per $\mathrm{ml}$ and sprayed onto trees within $1 \mathrm{~h}$ of preparation at a rate of about 3 liters per tree.

Enumeration of bacterial populations on trees. Epiphytic bacterial populations on 25 individual fruiting spurs were estimated for each treatment. Individual flowers or fruiting spurs were placed in small, sterile, sealable plastic bags immediately after collection in the field, transported on ice to the laboratory within about $4 \mathrm{~h}$, and 8 or $100 \mathrm{ml}$ of sterile washing buffer (31) was added to the bags. The tissues were submerged in the buffer, and the bags were sonicated for $7 \mathrm{~min}$ in an ultrasonic cleaning bath (Bransonic 52; Branson Ultrasonic Corp., Danbury, CT) to dislodge bacteria from the leaves (31). The bags were then manually agitated for $10 \mathrm{~s}$ to disperse the bacterial cells. An appropriate dilution of the tissue washing was then plated onto KB and KBR using a spiral diluter/ dispenser. Total bacteria was counted after 4 days of growth on $\mathrm{KB}$ at $24^{\circ} \mathrm{C}$. Bacteria resembling inoculated strains were enumerated on KBR after 3 days of incubation at $24^{\circ} \mathrm{C}$.

Measurement of fruit russet. A total of about 100 fruit was collected from each replicate of each treatment in experimental sites. In surveys of commercial orchards, a total of 400 fruit was collected randomly from 100 trees in each orchard in the vicinity of where samples of fruiting spurs were collected for enumeration of bacterial populations. The severity of fruit russet was estimated visually for each fruit using assessment keys composed of photographs of fruit for which the severity of lenticel russet had been quantified using a digital image analysis system (24). Occasional surface injury to fruit due to physical abrasion with limbs or insect injury was disregarded while assessing fruit russet. Emphasis was placed on the severity of fruit russet on the large hemisphere of the fruit where lenticel russet is more prominent. In most studies, a single individual rated all of the fruit from a given experiment.

Statistical methods. The goodness-of-fit of the normal distribution of log-transformed bacterial population sizes of individual tissue samples was tested by the Shapiro-Wilk $W$ statistic and calculated using SAS (release 6.04; SAS Institute, Cary, NC). Since most distributions were adequately described by a log-normal distribution, all estimates of bacterial population sizes were log-transformed prior to analysis. All measurements of fruit russet, expressed as the percentage of the fruit surface damaged, were subjected to inverse sine transformation before analysis. Analysis of variance (ANOVA) was performed on mean russet severity calculated from the many fruit scored for each replication. ANOVA of log-transformed, epiphytic bacterial population sizes was computed using the General Linear Models procedure of SAS. Separation of treatment means was performed by Fisher's unprotected least significant difference test; this method controls the comparison-wise error rate.

\section{RESULTS}

Survey of IAA production in epiphytic bacteria. A relatively high percentage of epiphytic bacteria on pear leaf and fruit surfaces produced IAA in culture media supplemented with tryptophan. Initial estimates of IAA production were made by analysis of culture supernatants with a colorimetric assay that is reasonably specific for IAA. A wide range of values for measured red chromophore production, indicative of the presence of IAA and possibly other indoles, was observed among a collection of 487 and 257 epiphytic bacteria isolated randomly from among the predominant bacterial microflora of pear spurs in two different commercial pear orchards (Fig. 1). The frequency distribution of the magnitude of the colorimetric reactions was strongly right-hand-skewed in both samples; the culture supernatant of most strains exhibited an optical density when measured at $530 \mathrm{~nm}\left(\mathrm{OD}_{530}\right)$ of less than 0.3 , while some had an $\mathrm{OD}_{530}$ greater than 1.5 (Fig. 1). On average, about $25 \%$ of the strains assayed exhibited an $\mathrm{OD}_{530}$ greater than 0.5 (Fig. 1).

A colorimetric reaction of culture supernatants yielded a good estimate of the IAA production by a collection of epiphytic bacteria.
Since this reagent can yield at least small amounts of red products with some other indole compounds besides IAA, we compared the estimates of IAA determined in culture supernatants from colorimetric assays with those determined using HPLC for a subset of 41 of the strains. The strains for this analysis represented those yielding a colorimetric reaction that ranged from nearly undetectable to those yielding an $\mathrm{OD}_{530}$ greater than 1.5. In general, the magnitude of the colorimetric reaction was proportional to the amount of IAA measured in the supernatants by HPLC (Fig. 2). Importantly, none of the culture supernatants of strains that yielded small colorimetric reactions contained large amounts of IAA, and none of those that yielded a high colorimetric reaction contained low amounts of IAA (Fig. 2). The concentration of IAA estimated from the colorimetric reaction was greater than about twice that expected from HPLC measurements for only four of the strains tested (Fig. 2). A wide range of measured IAA production of individual strains was observed; IAA was undetectable in the super-
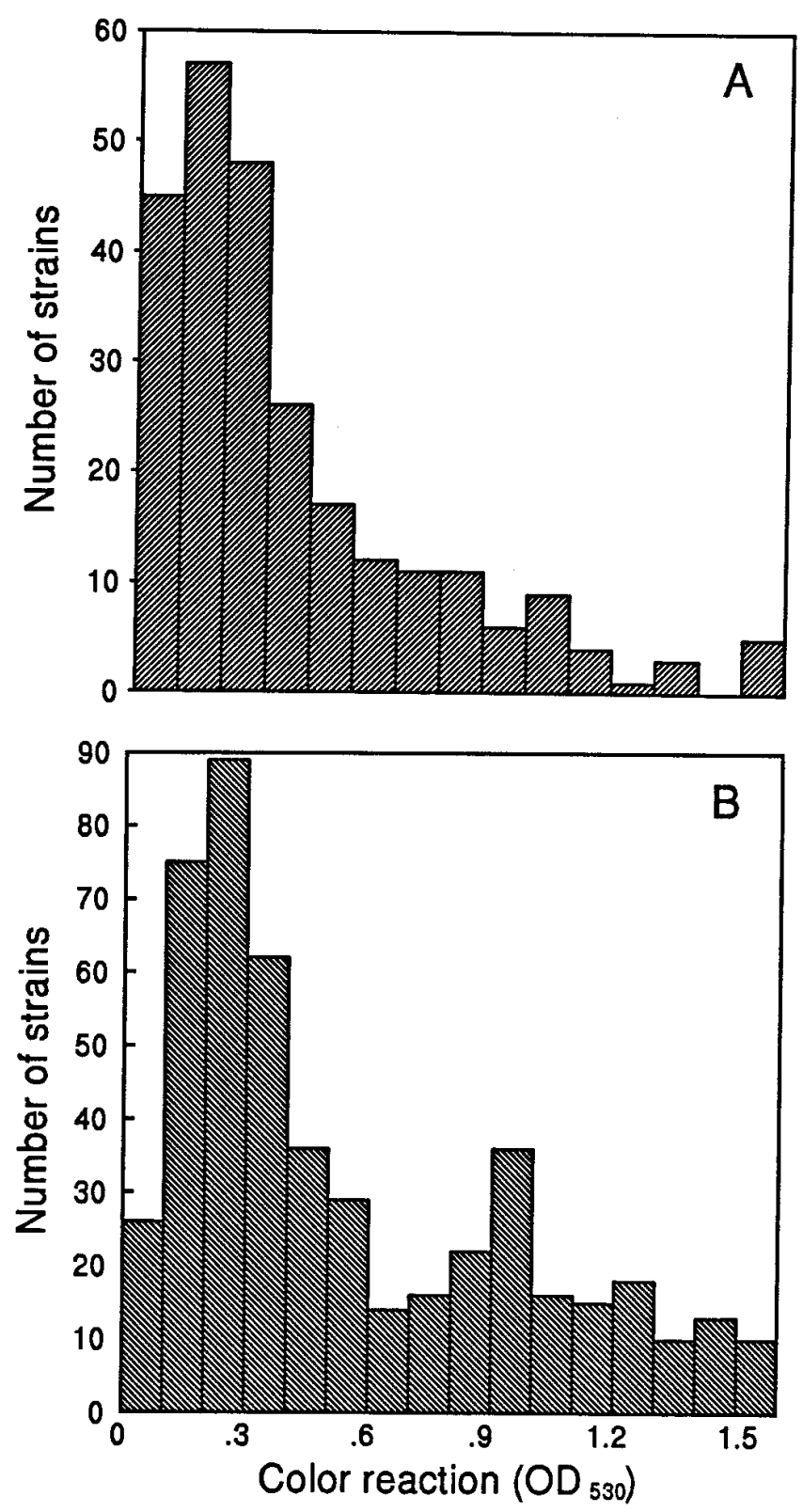

Fig. 1. Estimated indole-3-acetic acid (IAA) production by bacteria recovered from healthy leaves and flowers of 'Bartlett' pear trees in commercial orchards A, near Hopland, CA, in March 1990 and B, near Ukiah, CA, in 1993. The intensity of the red colorimetric reaction resulting after the addition of Salkowski reagent, which is maximally responsive to IAA, to culture supernatants, which is indicative of IAA, was quantified at a wavelength of $530 \mathrm{~nm}$. 
natants of some cultures, while more than $130 \mu \mathrm{g} / \mathrm{ml}$ occurred in others (Fig. 2). Two strains that produced about $130 \mu \mathrm{g} / \mathrm{ml}$ yielded high colorimetric reactions $\left(\mathrm{OD}_{530}>2.5\right)$, but less than expected for the high amounts of IAA detected by HPLC (Fig. 2).

A variety of bacterial species were observed to produce IAA. At least a few representative strains of E. herbicola, fluorescent Pseudomonas species, and other gram-negative nonpigmented bacteria were observed to produce high amounts of IAA in culture $\left(\mathrm{OD}_{530}>\right.$ 1.0). The 487 bacterial strains that were evaluated for IAA production at one site were grouped into broad taxonomic categories based on easily observed phenotypes (Fig. 3). Of the 118 strains that produced high amounts of IAA $\left(\mathrm{OD}_{530}>1.0\right), 42(36 \%)$ were yellow-pigmented facultative anaerobic strains resembling $E$. herbicola. Of the strains that produced very high amounts of IAA $\left(\mathrm{OD}_{530}>1.5\right), 70 \%$ resembled E. herbicola. All of 22 representative strains in this group that were characterized using GC-FAME analysis were identified as either E. herbicola or the closely related species Enterobacter agglomerans. High IAA production $\left(\mathrm{OD}_{530}>\right.$ $1.0)$ occurred in 42 out of 159 E. herbicola strains (26\%). In contrast, only 11 out of 218 fluorescent Pseudomonas species (5\%) produced high concentrations of IAA, and only $0.4 \%$ produced very high concentrations. Seventeen pseudomonad strains that produced high concentrations of IAA in culture were identified using GC-FAME analysis; nine were identified as $P$. syringae, one as $P$. viridiflava, five as $P$. fluorescens, and two as $P$. putida. A minority of strains that produced IAA could not be grouped with $E$. herbicola or fluorescent Pseudomonas species based on their cultural characteristics. This group was composed mostly of nonpigmented gram-negative strains, although a few resembling Xanthomonas species were observed. A total of 29 out of $125(23 \%)$ strains in this group produced high amounts of IAA $\left(\mathrm{OD}_{530}>1.0\right)$. None of the strains resembling Xanthomonas produced high concentrations of IAA. The three members of this group that were characterized by GC-FAME analysis were identified as Rahnella aquaticus.

The indole compounds produced by several epiphytic bacteria recovered from pear were analyzed to determine which biosynthetic pathway was used to produce IAA. Indole compounds ex-

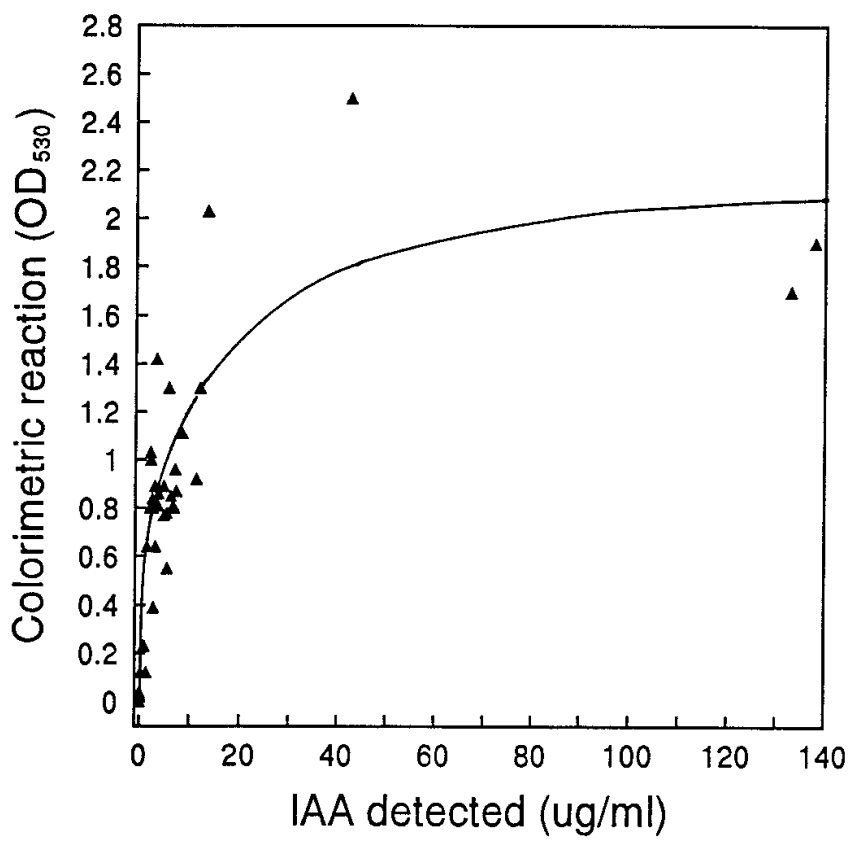

Fig. 2. Relationship between the quantity of indole-3-acetic acid (IAA) measured in culture supernatants of a variety of bacteria isolated from pear trees by high-performance liquid chromatography analysis (ordinate) and the estimated concentration of IAA in the supernatants determined as the intensity of a colorimetric reaction after the addition of Salkowski reagent (abscissa). Each point represents the estimation of IAA content in culture supernatants by these two methods for a given bacterial strain. tracted from culture supernatants were separated and compared with authentic standards using TLC. All of the 20 IAA-producing strains of $E$. herbicola that were examined produced both tryptophol (TOL) and indole-3-pyruvic acid (IPyA) in addition to IAA. Nearly all of these strains also produced at least some indole. Both of the two $R$. aquaticus strains tested also produced both TOL and IPyA. Of the seven strains identified as species of Pseudomonas, four produced indole-3-acetamide (IAM) and not TOL or IPyA. Three of these strains produced small amounts of TOL and IPyA in addition to IAA. All of the strains that produced IAM were identified as $P$. syringae; however, two of the three strains that produced TOL and IPyA were also identified as P. syringae.

Southern hybridization analysis was performed with an internal SacI-EcoRV fragment of the ipdC gene (encoding indolepyruvate decarboxylase) of E. herbicola $299 \mathrm{R}$ as a probe on the total DNA of a subsample of strains that produced IAA in our survey. The ipdC probe hybridized to the DNA of 18 out of 22 strains. All the strains showing a hybridization signal were identified as E. herbicola and produced TOL in tryptophan-supplemented culture media, while the strains that failed to hybridize to the probe were Pseudomonas species, including two strains that produced low levels of TOL.

Induction of fruit russet in field studies. IAA-producing bacteria isolated primarily from pear leaves and fruit were inoculated onto pear trees a single time at full bloom to determine if increasing the abundance of IAA-producing bacteria could increase fruit russet. Fruit russet was increased in 31 out of 37 treatments in which IAA-producing bacteria were applied to trees in trials conducted over a 6-year period (Table 1). All IAA-producing bacteria applied to trees increased fruit russet significantly in at least one experiment. Generally, applied bacteria that did not produce IAA did not

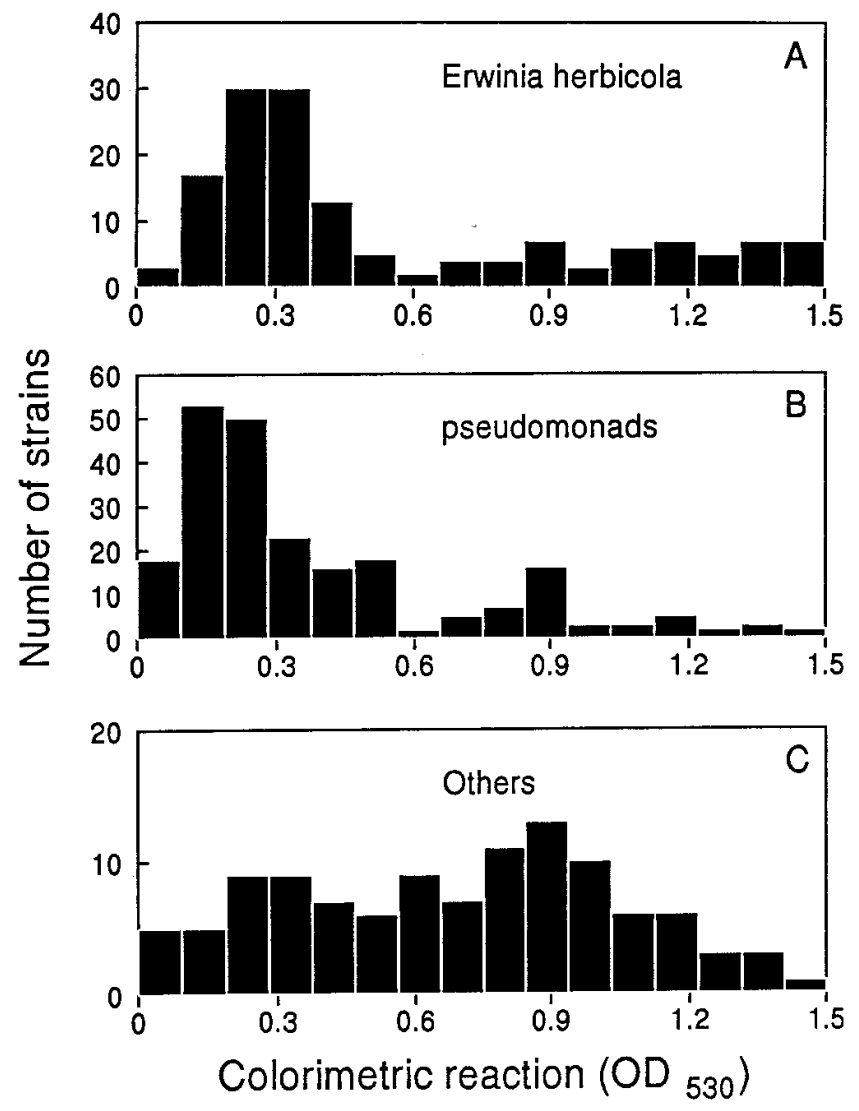

Fig. 3. Estimated indole-3-acetic acid (IAA) production by strains of different taxonomic groups of bacteria recovered from the surface of pear leaves and flowers in 1993. IAA production was quantified as the intensity of the colorimetric reaction of culture supernatants with Salkowski reagent. IAA production by strains resembling $\mathbf{A}$, Erwinia herbicola; $\mathbf{B}$, fluorescent pseudomonads; or $\mathbf{C}$, not having distinguishing characteristics is illustrated in each frequency histogram. 
increase fruit russet significantly (four of seven trials) or increased russet only a small amount (three of seven trials) (Tables 1 and 2). The application of tryptophan, the main precursor of IAA, with bacterial inocula always increased fruit russet over bacteria alone (Table 1; other data not shown). The application of tryptophan alone also increased fruit russet compared with control trees in each of four trials; in two of the four trials, the severity of russet in the presence of tryptophan was significantly $(P<0.05)$ greater than the untreated control (Tables 1 and 2).

The severity of fruit russet was altered by the application of plant growth regulators. Fruit russet was significantly lower on trees treated twice shortly after bloom with GA4+7 than on untreated control trees (Table 1) and was higher on trees treated twice with NAA than on untreated control trees; however, in only one treatment was this effect significant (Tables 1 and 2).

The consistency with which russet could be induced by the application of IAA-producing bacteria was evaluated by applying a mixture of four such bacteria in at least one trial in each of 5 years. The severity of fruit russet was significantly increased on trees treated with IAA-producing bacteria in eight out of nine trials (Table 2). While the severity of fruit russet varied greatly even on untreated control trees between years, and sometimes between trials

TABLE 1. Severity of fruit russet at harvest on 'Bartlett' pear trees treated during flowering with indole-3-acetic acid (IAA)-producing and nonproducing bacteria

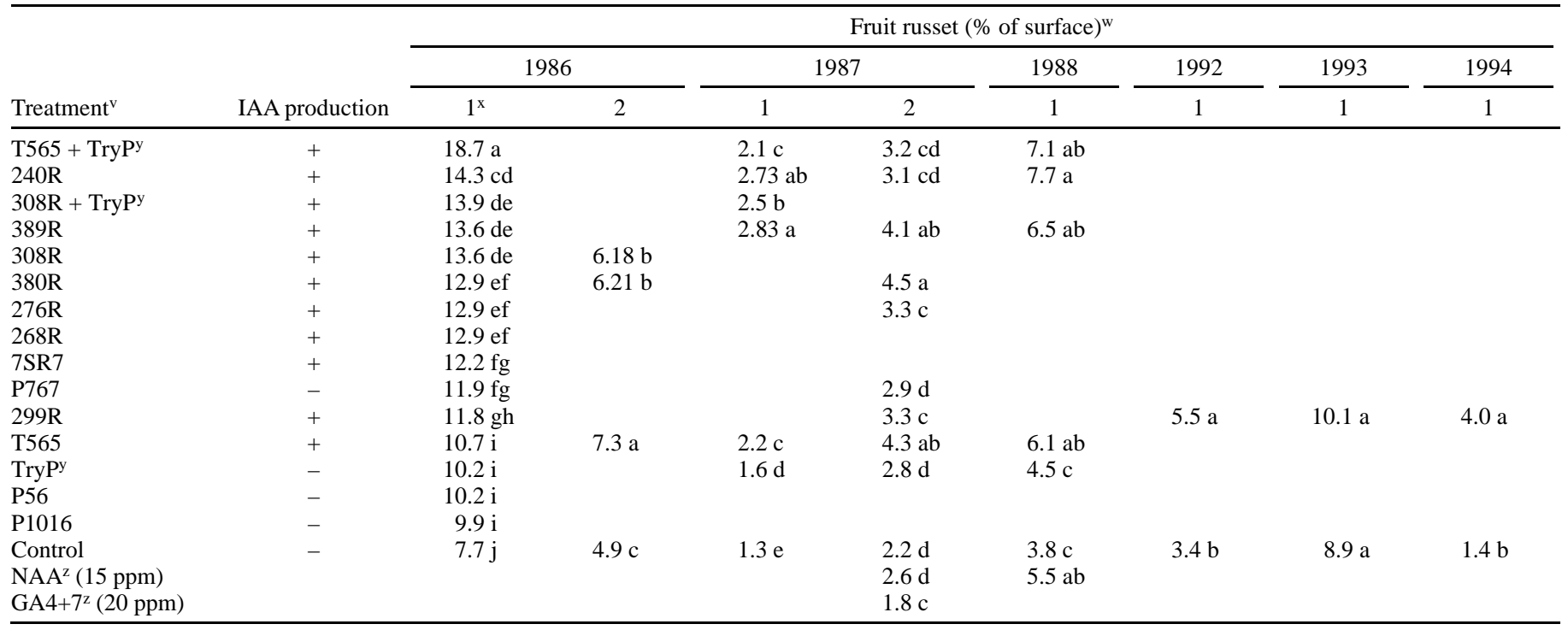

$\checkmark$ Bacterial strains applied once at about full bloom.

${ }^{\text {w }}$ Means within a column not followed by a common letter are not significantly different $(P=0.05)$ according to Fisher's unprotected least significant difference test.

${ }^{\mathrm{x}}$ Each number denotes a separate trial during a given year.

y Tryptophan applied alone or added to bacterial inoculum at a concentration of $100 \mathrm{mg} / \mathrm{liter}$.

z NAA = naphthalene acetic acid. GA4+7 = giberellic acid GA4+7.

TABLE 2. Severity of fruit russet on 'Bartlett' pear trees treated at flowering with a mixture of indole-3-acetic acid (IAA)-producing or with nonproducing bacteria

\begin{tabular}{|c|c|c|c|c|c|c|c|c|c|c|}
\hline \multirow[b]{3}{*}{ Treatment $^{\mathrm{W}}$} & \multirow[b]{3}{*}{ IAA production } & \multicolumn{9}{|c|}{ Fruit russet $(\% \text { of surface })^{\mathrm{x}}$} \\
\hline & & \multirow{2}{*}{$\frac{1986}{1^{\mathrm{y}}}$} & \multicolumn{2}{|c|}{1987} & \multicolumn{3}{|c|}{1988} & \multicolumn{2}{|c|}{1989} & \multirow{2}{*}{$\frac{1990}{1}$} \\
\hline & & & 1 & 2 & 1 & 2 & 3 & 1 & 2 & \\
\hline Control & - & $3.2 \mathrm{~b}$ & $1.4 \mathrm{~b}$ & $1.0 \mathrm{~b}$ & $1.7 \mathrm{a}$ & $1.9 \mathrm{~b}$ & $3.0 \mathrm{~b}$ & $7.7 \mathrm{~b}$ & $4.8 \mathrm{~b}$ & $2.5 \mathrm{~b}$ \\
\hline Mix of IAA $^{+}$bacteria & + & $6.0 \mathrm{a}$ & $2.1 \mathrm{a}$ & $1.5 \mathrm{a}$ & $1.6 \mathrm{a}$ & $3.3 \mathrm{a}$ & $4.4 \mathrm{a}$ & $10.0 \mathrm{a}$ & $6.5 \mathrm{a}$ & $3.1 \mathrm{a}$ \\
\hline P1016 & - & & $1.4 \mathrm{~b}$ & & & & $3.2 \mathrm{~b}$ & & $4.6 \mathrm{~b}$ & \\
\hline A506 & - & $2.8 \mathrm{~b}$ & $1.3 \mathrm{~b}$ & $1.2 \mathrm{~b}$ & $1.6 \mathrm{a}$ & $1.8 \mathrm{~b}$ & $3.1 \mathrm{~b}$ & $8.8 \mathrm{ab}$ & $5.2 \mathrm{~b}$ & $1.6 \mathrm{c}$ \\
\hline A526 & - & $3.3 \mathrm{~b}$ & & $0.8 \mathrm{c}$ & & & & & & \\
\hline $\mathrm{NAA}^{\mathrm{z}}(15 \mathrm{ppm})$ & & & & & & & & & $6.3 \mathrm{a}$ & \\
\hline
\end{tabular}

${ }^{\mathrm{w}}$ Bacterial strains applied once at about full bloom.

${ }^{x}$ Means within a column not followed by a common letter are significantly different $(P=0.05)$ according to Fisher's unprotected least significant difference test.

y Each number denotes a separate trial during a given year.

z NAA $=$ naphthalene acetic acid.

TABLE 3. Severity of fruit russet on 'Bartlett' pear trees treated at flowering with antibiotics, with bacteria, or both that do not produce indole-3-acetic acid

\begin{tabular}{|c|c|c|c|c|c|c|c|c|c|c|c|c|c|c|c|c|c|c|c|c|c|c|c|c|c|}
\hline \multirow[b]{3}{*}{ Treatment } & \multicolumn{25}{|c|}{ Fruit russet $(\% \text { of surface })^{\mathrm{x}}$} \\
\hline & \multicolumn{2}{|c|}{1985} & \multicolumn{2}{|c|}{1986} & \multirow{2}{*}{$\frac{1987}{1}$} & \multirow{2}{*}{$\frac{1989}{1}$} & \multicolumn{3}{|c|}{1990} & \multicolumn{4}{|c|}{1991} & \multicolumn{6}{|c|}{1992} & \multirow{2}{*}{$\frac{1993}{1}$} & \multicolumn{3}{|c|}{1994} & \multicolumn{2}{|c|}{1995} \\
\hline & $1^{\mathrm{y}}$ & 2 & 1 & 2 & & & 1 & 2 & 3 & 1 & 2 & 3 & 4 & 1 & 2 & 3 & 4 & 5 & 6 & & 1 & 2 & 3 & 1 & 2 \\
\hline Control & $2.4 \mathrm{a}$ & $3.5 \mathrm{a}$ & $6.1 \mathrm{a}$ & $10.9 \mathrm{a}$ & $0.6 \mathrm{~b}$ & $9.1 \mathrm{a}$ & & & $2.3 \mathrm{a}$ & $* \mathrm{Z}$ & * & * & $3.7 \mathrm{a}$ & $*$ & & & & & $3.4 \mathrm{a}$ & $9.0 \mathrm{a}$ & $*$ & $*$ & $*$ & $16.8 \mathrm{a}$ & $*$ \\
\hline A506 & $2.2 \mathrm{a}$ & $2.2 \mathrm{c}$ & $5.3 \mathrm{~b}$ & $9.9 \mathrm{ab}$ & $0.9 \mathrm{a}$ & $10.7 \mathrm{a}$ & & & & & & & $1.7 \mathrm{~b}$ & & & & & & $2.2 \mathrm{a}$ & $7.0 \mathrm{a}$ & & & & $15.2 \mathrm{a}$ & \\
\hline A526 & $2.1 \mathrm{a}$ & $2.4 \mathrm{c}$ & & $9.0 \mathrm{~b}$ & $0.8 \mathrm{~b}$ & & & & & & & & & & & & & & & & & & & & \\
\hline $\begin{array}{l}\text { Streptomycin } \\
\text { Terramycin }\end{array}$ & $\begin{array}{l}2.4 \mathrm{a} \\
3.2 \mathrm{a}\end{array}$ & $2.6 \mathrm{~b}$ & $5.2 \mathrm{~b}$ & $9.4 \mathrm{ab}$ & $1.1 a$ & & $1.5 \mathrm{a}$ & $5.3 \mathrm{a}$ & $2.8 \mathrm{a}$ & $8.2 \mathrm{a}$ & $11.6 \mathrm{a}$ & $7.7 \mathrm{a}$ & & $3.6 \mathrm{a}$ & $6.9 \mathrm{a}$ & $2.5 \mathrm{a}$ & $3.3 \mathrm{a}$ & $4.3 \mathrm{a}$ & $7.0 \mathrm{a}$ & $8.4 \mathrm{a}$ & $2.6 \mathrm{a}$ & $2.4 \mathrm{a}$ & $2.0 \mathrm{a}$ & & $10.9 \mathrm{a}$ \\
\hline $\begin{array}{l}\text { A506 + } \\
\text { Streptomycin }\end{array}$ & $2.2 \mathrm{a}$ & & $3.3 \mathrm{c}$ & $10.0 \mathrm{ab}$ & & & $0.8 \mathrm{~b}$ & $3.7 \mathrm{~b}$ & $2.4 \mathrm{a}$ & $6.1 \mathrm{~b}$ & $7.2 \mathrm{~b}$ & $5.4 \mathrm{~b}$ & & $1.9 \mathrm{~b}$ & $5.9 \mathrm{~b}$ & $1.5 \mathrm{~b}$ & $2.3 \mathrm{a}$ & $3.1 \mathrm{a}$ & & $6.8 \mathrm{a}$ & $1.2 \mathrm{~b}$ & $1.4 \mathrm{~b}$ & $1.1 \mathrm{~b}$ & $15.0 \mathrm{a}$ & $9.6 \mathrm{a}$ \\
\hline $\begin{array}{l}\text { A506 + } \\
\text { Terramycin }\end{array}$ & & & & & $1.0 \mathrm{a}$ & $10.1 \mathrm{a}$ & & & & & & & & & & & & & $3.2 \mathrm{a}$ & & & & & & \\
\hline
\end{tabular}

${ }^{\mathrm{x}}$ Means within a column not followed by a common letter are not significantly different $(P=0.05)$ according to Fisher's unprotected least significant difference test.

${ }^{y}$ Each number denotes a separate trial during a given year.

${ }^{\mathrm{z}}$ Untreated control not included in this trial. Pseudomonas fluorescens strain A506 applied in combination with an antibiotic is compared with that of antibiotic applied alone. 
at different sites in the same year, IAA-producing bacteria increased russet by an average of 1.44 -fold in these trials (Table 2).

The severity of fruit russet was often less on trees treated with $P$. fluorescens strain A506, a bacterium that can prevent the growth of E. amylovora and ice nucleation active bacteria such as $P$. syringae by preemptive competitive exclusion. The severity of fruit russet was evaluated on trees on which $P$. fluorescens strain A506 was applied alone or in combination with either streptomycin or oxytetracycline in 36 treatments conducted in 34 trials over a period of 10 years. In 30 out of 36 cases in which trees were treated with $P$. fluorescens strain A506, the severity of fruit russet was numerically lower than on control trees; in 15 out of these 36 cases, the difference was statistically significant $(P<0.05)$ (Tables 2 and 3 ). On average, the russet severity was about $77 \%$ that on control trees (Tables 2 and 3). Similar reductions in russet severity were observed on trees treated with $P$. fluorescens strain A526 (Tables 2 and 3).

The application of streptomycin or oxytetracycline alone to trees had little effect on fruit russet. The fruit russet on trees treated with either of these antibiotics alone was compared with that on untreated control trees in eight different trials. In five of the nine cases, the severity of fruit russet was higher on treated trees than on the control trees; in only two cases was this difference statistically significant (Table 3). In two cases, fruit russet was significantly lower on treated trees than on control trees. On average, fruit russet on antibiotic-treated trees was $120 \%$ of that on untreated control trees (Table 3).

Colonization of trees with IAA-producing bacteria. Many IAA-producing bacteria rapidly established large population sizes on pear tissues after inoculation of trees at full bloom. As much as $50 \%$ of the cells recovered from pear spurs of treated trees were the inoculated strain when effective colonizers such as E. herbicola strain 299R were applied (Fig. 4). The total bacterial population size was not usually altered by the application of IAA-producing bacteria (Fig. 4). The population size of some IAA-producing bacteria, especially those usually found in the rhizosphere of plants other than pear, were usually lower than good colonizers such as E. herbicola strain 299R (data not shown). Since the amount of

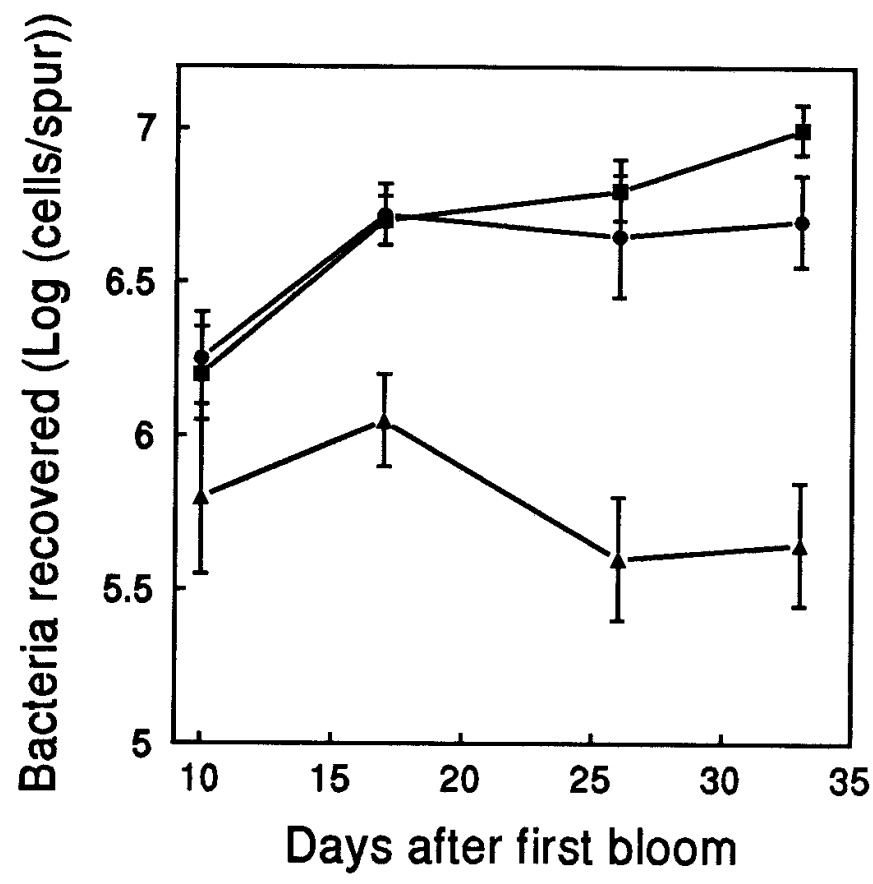

Fig. 4. Total bacterial population size (circles) and population size of Erwinia herbicola strain 299R (triangles) at various times after inoculation onto 'Bartlett' pear trees at 5 days after first bloom. The total bacterial population size on untreated control trees (squares) is also shown. The vertical bars represent the standard error of the determination of mean log-transformed population sizes on individual pear spurs.
IAA produced by the IAA-producing bacteria applied to pear varied in culture, an estimate of potential exogenous IAA production for each strain was generated as the product of the mean log-transformed population size of that strain in the first 3 weeks after inoculation onto trees and the relative amount of IAA produced by that strain in tryptophan-amended culture media. A significant linear relationship between exogenous IAA production, expressed as mean log-transformed normalized population size of IAA-producing bacteria, and the severity of fruit russet was observed (Fig. 5). Those strains that achieved the highest population size, that were capable of producing the highest amounts of IAA in culture media, or both incited the highest severity of fruit russet. There was a substantial amount of fruit russet even on trees in which inoculated IAA-producing bacteria did not establish high population sizes; presumably, indigenous bacterial populations contributed to this fruit russet. Similar relationships were observed in other experiments (data not shown).

The total bacterial population size on pear in several commercial orchards was measured periodically during the several weeks following bloom in each of 10 consecutive years to relate indigenous bacterial population sizes with the severity of fruit russet. The average total bacterial population size was measured during the period of full bloom to about 30 days later (from about midMarch to mid-April). Even though the pear trees in these surveys had received similar management inputs (similar antibiotic and fungicide sprays) in each year and at all sites, the total bacterial population sizes varied greatly from year to year and site to site (Fig. 6). Bacterial populations were generally much lower in some years such as 1987 and 1990 (averaging less than about $10^{5}$ cells per g) than in years such as 1993 and 1995, when over $10^{6}$ cells per $g$ could be recovered from pear tissues (Fig. 6). The severity of fruit russet was measured at harvest in all sampled orchards and also varied greatly from year to year and from site to site, ranging from less than $1 \%$ to greater than $16 \%$ of the fruit surface (Fig. 6). There was a strong linear correlation of the logarithm of total bacterial population sizes with fruit russet severity $\left(P<0.0001, R^{2}=\right.$ 0.44) (Fig. 6).

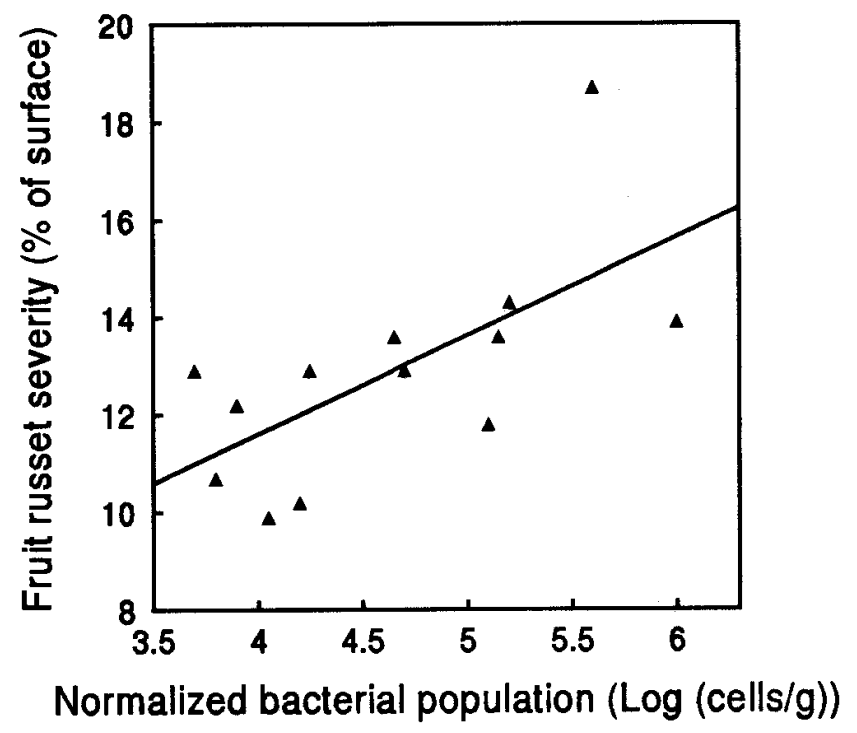

Fig. 5. Relationship between estimated total indole-3-acetic acid (IAA)-production potential on pear trees inoculated at flowering with different IAAproducing bacterial strains and the severity of fruit russet at harvest. The arithmetic back-transformed mean of log-transformed bacterial population sizes measured on trees in the first 30 days after inoculation was normalized by the relative amount of IAA produced in culture (estimated by colorimetric reactions with Salkowski reagent) to estimate IAA-production potential on trees. The log-transformed normalized population size for each bacterial strain inoculated onto trees in an experimental plot established in Healdsburg, CA, in 1986 is displayed on the abscissa. The line drawn represents the best-fit linear regression $Y=2.01 X+3.53 ; R^{2}=0.43(P=0.015)$. 


\section{DISCUSSION}

A substantial fraction of the epiphytic bacteria on plants apparently have the ability to produce IAA. However, there has not been a systematic examination of the phenomenon of bacterial IAA production among epiphytic bacteria. This phenotype has been more extensively studied in plant-pathogenic and symbiotic bacteria. Several of these plant-associated bacteria have been demonstrated to produce IAA in culture, and in the case of gall-forming pathogens, IAA production plays an important role in the symptomatology of the disease $(6,32)$. In other leaf-infecting pathogens such as strains of $P$. syringae and $X$. campestris, the role of exogenous IAA production of which these species are capable is not clear $(12,32$, 40). It is interesting to note that many bacterial strains from the rhizosphere of plants can increase root elongation when inoculated onto a variety of plants $(2,9,25,32,43)$. It seems likely that roots respond positively to small amounts of exogenous IAA that such bacterial strains can produce in situ $(33,36)$. Interestingly, strains that have the potential to produce high amounts of IAA in culture often reduce root elongation, apparently by producing levels of IAA in situ that is inhibitory to roots $(9,25,33,36,43)$. Since the rhizobacterial strains that have been characterized for IAA production in vitro are generally those that either enhanced or inhibited plant growth, it is difficult to estimate the fraction of rhizosphere bacteria that can produce IAA. Since such a high percentage of the rhizosphere strains that have been characterized can produce at least some IAA in vitro, the incidence of this phenotype in bacteria on roots may be similar to the high incidence estimated in the phyllosphere in this study.

The ability of bacteria to produce IAA in vitro is apparently a quantitative rather than a qualitative trait. The amounts of IAA produced in vitro varied greatly, ranging from nearly undetectable to extremely high quantities (Figs. 1 and 2). For this reason, it is difficult to indicate unambiguously what fraction of strains on plants are potentially IAA producers. As many as $50 \%$ of the strains examined in this study had the ability to produce at least small amounts of IAA in vitro (Figs. 1 and 2). In contrast, only about $25 \%$ produced large amounts of IAA in culture $\left(\mathrm{OD}_{530}>1.0\right.$; approximately $5 \mu \mathrm{g}$ of IAA per $\mathrm{ml}$ ) (Figs. 1 and 2). The relationship between production of IAA in vitro and in planta is not well known. The production of IAA by many bacteria in culture is strongly influenced by the availability of tryptophan $(4,6,32)$. While tryptophan has been detected on some plants $(30,34,39)$, little is known of its availability on most plants. Loper and Schroth (25) have, however, found a strong correlation of IAA production in culture and root inhibition. Many of the bacterial strains found in this study produced higher amounts of IAA than those strains that Loper and Schroth (25) found to inhibit root elongation (Fig. 3); such strains might be expected to alter normal epidermal cell development and, thereby, induce russet.

Lenticels are the primary site of fruit russet in pear. Little is known of the colonization of lenticels of pear, although they are colonized in other plant species. Lenticels may, therefore, provide nutrient-rich microenvironments in which bacteria could produce IAA. Since IAA is very photo-labile, any IAA produced within lenticels may be more stable than that produced elsewhere on fruit surfaces. Alternatively, IAA produced in the vicinity of lenticels may more efficiently reach interior plant cells and induce alterations in development.

Strains of $E$. herbicola are the most common IAA-producing bacteria on pear tissues. A much higher percentage of the strains of this species than of other bacterial species recovered from pear could produce IAA in culture (Fig. 3). However, some of the strains capable of the highest IAA production in culture were identified as species of Pseudomonas, although IAA production was not as frequent within this group of bacteria as in E. herbicola (Fig. 3). Since E. herbicola is one of the most common bacteria isolated from leaves $(8,13)$, some of its success as an epiphyte may be attributed to its ability to produce IAA on plant surfaces.
A variety of pathways are apparently used for IAA production by bacterial epiphytes. While a detailed analysis of IAA biosynthetic pathways was outside of the scope of this study, some insight into the pathways used by epiphytes was gained by examination of the presence of intermediates involved in IAA production in culture supernatants. All IAA-producing E. herbicola strains produced TOL and IPyA as intermediates, and thus, resembled $E$. herbicola strain 299R and other E. herbicola strains that have been extensively characterized $(4,5,26)$. Surprisingly, some strains of Pseudomonas also produced these intermediates, and hence, resembled a few phytopathogenic strains that apparently use IPyA as a biosynthetic intermediate $(6,38)$. Some strains of $P$. syringae appeared to use the IAM biosynthetic pathway for IAA synthesis, like gall-forming members of this species (40). Non-gall-forming strains of $P$. syringae have also been shown to produce IAA in culture (40). Glickmann et al. (14) have also recently reported that most strains of $P$. syringae produce at least small amounts of IAA and that those strains producing the highest amounts harbored the iaaM/iaaH genes, and strains producing lesser amounts apparently used alternative pathways. Strains of $P$. syringae and $E$. herbicola from pear having either IAM or IPyA as IAA biosynthetic intermediates were capable both of producing very high amounts of IAA in culture $(>10 \mu \mathrm{g} / \mathrm{ml})$ and of inciting pear fruit russet. Hence, both biosynthetic pathways for IAA may be operative in bacteria on plants and potentially cause russet on fruits.

This study provided substantial evidence for the role of IAAproducing bacteria in fruit russet. The finding that the application of IAA-producing bacteria to trees consistently increased russet is strong evidence that they can be sufficient to incite russet. While the application of IAA-producing bacteria consistently increased the severity of fruit russet, this effect was often not dramatic; russet severity was often increased by less than about twofold (Tables 1 and 2). These results can be better interpreted after considering two factors identified during the course of these studies. First, and most importantly, high numbers of indigenous IAA-producing bacteria already occur on untreated trees. As many as $25 \%$ of the epiphytic

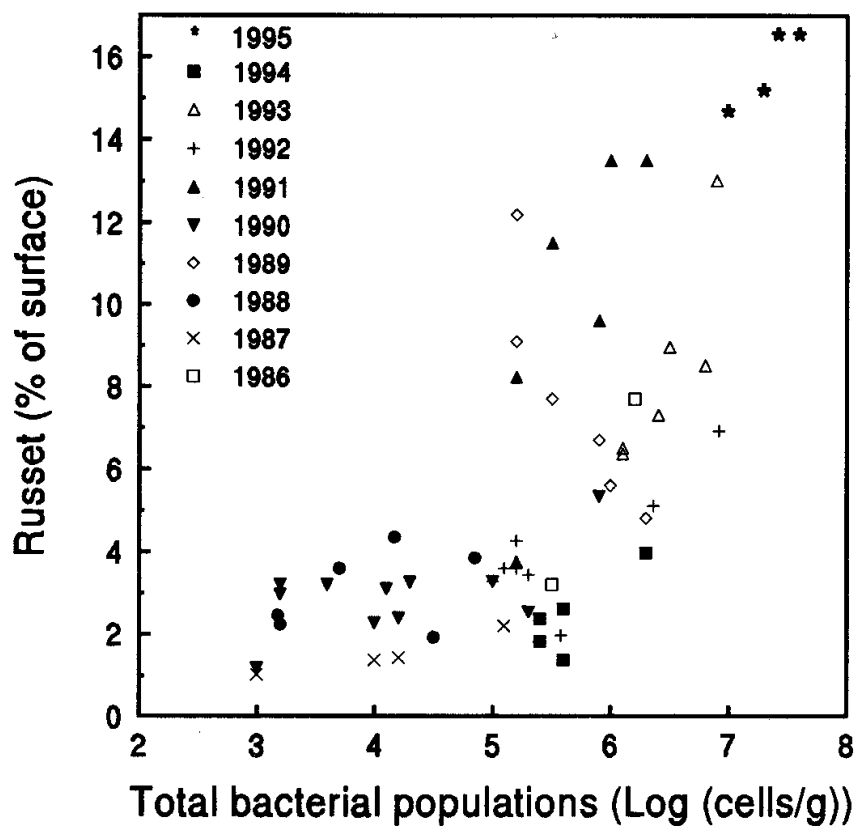

Fig. 6. Relationship between mean total bacterial population sizes measured on 'Bartlett' pear spurs in the first 30 days after first bloom and the severity of fruit russet at harvest. Pear spurs were harvested from several different commercial orchards in each of several years in the pear-growing regions in northern California. Mean log-transformed bacterial population sizes were estimated from two or more samplings of pear spurs in each orchard in each season. Each point represents estimates of fruit russet and bacterial population size for a single orchard in the year denoted in the legend. 
bacteria on pear can apparently produce large amounts of IAA. Inoculation with IAA-producing bacteria does not normally increase the total number of bacteria on trees (Fig. 5). Therefore, inoculation with IAA producers merely increases the proportion of the total microflora that are high IAA producers. In addition, in any given year, the number of bacteria that can become established on pear varies substantially (Fig. 6). The reasons for this variation are not known, but high population sizes are generally associated with moist environmental conditions in the spring. Hence, the environment of trees seems to limit the colonization of trees by epiphytic bacteria including IAA producers. The application of IAA-producing bacteria in the early spring simply changes the proportion of bacteria on trees that can produce high amounts of IAA. Increasing the proportion of IAA-producing bacteria on trees from about 25 to $50 \%$, as was achieved in this study (Fig. 3), should, thus, have resulted in the measurable and consistent, but usually not dramatic, increases in fruit russet that were observed in this study (Tables 1 and 2). The movement of IAA-producing bacteria from inoculated trees to control trees could also have reduced the apparent effect of inoculation on fruit russet. Indeed, cells of the inoculated IAAproducing bacteria were detected on control trees in this study.

The consistent reduction of fruit russet on trees treated with $P$. fluorescens strain A506 also provides strong evidence that indigenous IAA-producing bacteria incite russet. P. fluorescens strain A506 was shown to be a good colonizer of pear, representing up to $75 \%$ of the total bacterial cells on treated trees (23). P. fluorescens strain A506 can reduce the population size of both $P$. syringae and E. amylovora on pear by about 10 -fold or more by preemptive competition $(16,19,22,23,41)$. This study has shown that some of the bacteria capable of the highest levels of IAA production are strains of $P$. syringae; the abundance of such strains should have been reduced on pear by competition with $P$. fluorescens strain A506. While it is unknown if $P$. fluorescens strain A506 effectively competes with strains of E. herbicola, which are common IAA producers on pear, this seems likely to occur since biological control by this agent is apparently by preemptive utilization of limiting nutrient sources on plants (42). The broad nutrient-utilization capability of $P$. fluorescens strain A506 (42) should enable it to compete effectively with $E$. herbicola strains. Thus, the application of $P$. fluorescens strain A506 in the early spring, before epiphytic colonization of pear occurs, should result in substantial reductions in the population size of IAA-producing bacteria. Since there are a variety of IAA-producing bacterial species on pear, it was not possible to directly measure changes in the numbers of IAA producers on trees treated with $P$. fluorescens strain A506. We, therefore, can only estimate the magnitude of reductions in population sizes of IAA-producing bacteria. If the numbers of these bacteria were reduced 10-fold by $P$. fluorescens strain A506, similar to that of $P$. syringae or E. amylovora, the severity of fruit russet would have been reduced by the $30 \%$ observed in this study (Figs. 5 and 6; Tables 2 and 3). This expectation is supported by the finding that the relationship between the population size of inoculated IAAproducing bacteria and russet severity (Fig. 5) is similar to that between total indigenous bacteria (composed at least partially of IAA-producing bacteria) and russet severity (Fig. 6).

Biological control of fruit russet is an attractive strategy for managing this problem. While P. fluorescens strain A506 may not be the best antagonistic bacterium for fruit russet control, it is used to control frost injury and fire blight disease $(16,23)$. Hence, the finding that this strain can also reduce fruit russet should provide further incentive for pear growers to integrate the use of this biological control agent into their production systems. Since fruit russet is incited within a few weeks of pear bloom, management of IAAproducing bacteria within this relatively narrow time span should be feasible using biological control agents. P. fluorescens strain A506 was selected for the preemptive competitive exclusion of $P$. syringae and was only incidentally found to compete with $E$. amylovora $(20,23)$. Since E. herbicola strains appear to be the pre- dominant IAA producers on pear, superior antagonists for fruit russet control could probably be found.

The demonstration that the removal of IAA-producing bacteria could eliminate fruit russet would be strong evidence for their involvement in this phenomenon. Unfortunately, there is no practical way to eliminate IAA-producing bacteria from plants, especially from large pear trees. Both streptomycin and oxytetracycline had little or no effect on total bacterial population size on pear (23; S. E. Lindow, unpublished data). Our unpublished data show that 50 to $100 \%$ of the bacterial microflora on pear in orchards treated repeatedly with either streptomycin or oxytetracycline are resistant to these antibiotics, as in other studies (37). Most of the IAA-producing bacteria that we have characterized are resistant to one or both of these antibiotics (data not shown). Therefore, the application of these antibiotics to trees results in little change in total bacterial population sizes. Streptomycin or oxytetracycline may even have selectively killed non-IAA-producing bacteria in some orchards, resulting in increased population sizes of IAA-producing bacteria and, hence, more severe fruit russet (Tables 2 and 3).

The observation of a strong association of total bacteria on trees shortly after bloom and fruit russet at harvest has several implications for the management of russet. This relationship suggests that the proportion of the total bacteria on pear that produce IAA is similar in different orchards and in different years. If this were not true, greatly different russet severity would occur in orchards having similar total bacterial population sizes. While some variation in russet severity on trees with a given population size was observed (Fig. 6), this did not obscure an otherwise strong and direct relationship between bacterial population size and russet. Since high population sizes of IAA-producing bacteria early in the growing season confer fruit russet at harvest, it should be possible to predict those orchards or years when management strategies to control russet would be most beneficial. Measurement of early-season bacterial populations could be used to indicate the need for gibberellic acid to reduce the effects of IAA-producing bacteria or for chemical or biological treatments to reduce their population size to prevent russet.

This study has shown that there is a strong association of total bacterial populations and, presumably, IAA-producing bacteria with russet severity. Due to the strong effect of environment on epiphytic bacterial populations, the association of russet severity with environmental conditions can be explained. Although plant stress can lead to fruit russet $(11,38)$, it is not necessary to hypothesize stressinduced plant physiological alterations to which russet can be attributed, because this study has shown that IAA-producing bacteria can be sufficient to account for fruit russet. A recent preliminary report has also associated certain yeast and fungi with fruit russet of apple in another climatic zone (27). We can not discount the possibility that these microbes might also contribute to fruit russet of pear in California. In fact, one would expect populations of yeast and bacteria to be covariable; moist conditions would promote colonization by both groups of organisms.

\section{ACKNOWLEDGMENTS}

This research was supported, in part, by the California Pear Advisory Board and California Pear Zone, the Integrated Pest Management Program of the University of California, and Western Regional Research Project W-130. We thank B. Bearden, G. Vogel, and W. Reil for assistance in identifying and maintaining many of the research plots from which data are reported in the study; S. Thomas, J. Thomas, S. Maxie, K. Barr, and others for allowing us to use many 'Bartlett' pear trees in their orchards for this study; J. Benson for valuable assistance in maintaining field plots; G. Lim, C. Pierce, D. Okamoto, M. Owen, K. Callan, G. Andersen, L.-M. Gong, and A. Le for valuable assistance in harvesting of fruit, collection of tissue samples, determining the severity of fruit russet, and in enumerating bacterial populations throughout the course of this study. We thank V. Elliott for generously identifying many of the strains in this study using fatty acid methyl ester analysis. 


\section{LITERATURE CITED}

1. Andersen, G. L., Menkissoglou, O., and Lindow, S. E. 1991. Occurrence and properties of copper-tolerant strains of Pseudomonas syringae isolated from fruit trees in California. Phytopathology 81:648-656.

2. Barbieri, P., Zanelli, T., Galli, E., and Zanetti, G. 1986. Wheat inoculation with Azospirillum brasilense Sp6 and some mutants altered in nitrogen fixation and indole-3-acetic acid production. FEMS (Fed. Eur. Microbiol. Soc.) Microbiol. Lett. 36:87-90.

3. Bell. H. P. 1938. The origin of russetting in the golden russet apple. Can. J. Res. 15:560-566.

4. Brandl, M., Clark, E. M., and Lindow, S. E. 1996. Characterization of the indole-3-acetic acid (IAA) biosynthetic pathway in an epiphytic strain of Erwinia herbicola and IAA production in vitro. Can. J. Microbiol. 42:586-592.

5. Brandl, M. T., and Lindow, S. E. 1997. Cloning and characterization of a locus encoding an indolepyruvate decarboxylase involved in indole-3acetic acid synthesis in Erwinia herbicola. Appl. Environ. Microbiol. 62:4121-4128.

6. Costacurta, A., and Vanderleyden, J. 1995. Synthesis of phytohormones by plant-associated bacteria. Crit. Rev. Microbiol. 21:1-18.

7. DeVries, H. A. M. A. 1968. Development of the structure of the russetted apple skin. Acta Bot. Neerl. 17:405-415.

8. Dickinson, C. H., Austin, B., and Goodfellow, M. 1975. Quantitative and qualitative studies of phylloplane bacteria from Lolium perenne. J. Gen. Microbiol. 91:157-166.

9. Dubeikovsky, A. N., Mordukhova, E. A., Kochetkov, V. V., Polikarpova, F. Y., and Boronin, A. M. 1993. Growth promotion of blackcurrant softwood cuttings by recombinant strain Pseudomonas fluorescens BSP53a synthesizing an increased amount of indole-3-acetic acid. Soil Biol. Biochem. 25:1277-1281.

10. Ehmann, A. 1977. The Van Urk-Salkowski reagent-A sensitive and specific chromogenic reagent for silica gel thin-layer chromatographic detection and identification of indole derivatives. J. Chromatogr. 132:267-276.

11. Faust, M., and Shear, C. B. 1972. Russetting of apples: An interpretive review. Hortscience 7:233-234.

12. Fett, W. F., Osman, S. F., and Dunn, M. F. 1987. Auxin production by plant-pathogenic Pseudomonads and Xanthomonads. Appl. Environ. Microbiol. 53:1839-1845.

13. Gibbins, L. N. 1978. Erwinia herbicola: A review and perspective. Pages 401-442 in: Proc. Int. Conf. Plant Pathogenic Bacteria, 4th. Inst. Natl. Rech. Agron, Angers, France.

14. Glickmann, E., Gardan, L., Jacquet, S., Hussain, S., Elasri, M., Petit, A., and Dessaux, Y. 1998. Auxin production is a common feature of most pathovars of Pseudomonas syringae. Mol. Plant-Microbe Interact. 11:156-162.

15. Gordon, S. A., and Weber, R. P. 1951. Colorimetric estimation of indoleacetic acid. Plant Physiol. 26:192-195.

16. Johnson, K. B., Stockwell, V. O., McLaughlin, R. J., Sugar, D., Loper, J. E., and Roberts, R. G. 1993. Effect of antagonistic bacteria on establishment of honey bee-dispersed Erwinia amylovora in pear blossoms and on fire blight control. Phytopathology 83:995-1002.

17. Jones, K. M., Koen, T. B., Bound, S. A., and Oakford, M. J. 1991. Some reservations in thinning "Fuji" apples with naphthalene acetic acid (NAA) and ethephon. N.Z. J. Crop Hortic. Sci. 19:225-228.

18. King, E. O., Ward, M. K., and Raney, D. E. 1954. Two simple media for the demonstration of pyocyanin and fluorescein. J. Lab. Clin. Med. 44: 301-307.

19. Lindow, S. E. 1983. Methods of preventing frost injury caused by epiphytic ice-nucleation-active bacteria. Plant Dis. 67:327-333.

20. Lindow, S. E. 1985. Integrated control and role of antibiosis in biological control of fireblight and frost injury. Pages 83-115 in: Biological Control on the Phylloplane. C. Windels and S. E. Lindow, eds. The American Phytopathological Society, St. Paul, MN.
21. Lindow, S. E. 1985. Strategies and practice of biological control of ice nucleation active bacteria on plants. Pages 293-311 in: Microbiology of the Phyllosphere. N. Fokkema, ed. Cambridge University Press, London.

22. Lindow, S. E. 1995. Control of epiphytic ice nucleation-active bacteria for management of plant frost injury. Pages 239-256 in: Biological Ice Nucleation and Its Applications. R. E. Lee, G. J. Warren, and L. V. Gusta, eds. The American Phytopathological Society, St. Paul, MN.

23. Lindow, S. E., McGourty, G., and Elkins, R. 1996. Interactions of antibiotics with Pseudomonas fluorescens strain A506 in the control of fire blight and frost injury to pear. Phytopathology 86:841-848.

24. Lindow, S. E., and Webb, R. R. 1983. Quantification of foliar plant disease symptoms by microcomputer-digitized video image analysis. Phytopathology 73:520-524.

25. Loper, J. E., and Schroth, M. N. 1986. Influence of bacterial sources of indole-3-acetic acid on root elongation of sugar beet. Phytopathology 76:386-389.

26. Manulis, S., Valinski, L., Gafni, Y., and Hershenhorn, J. 1991. Indole-3acetic acid biosynthesis pathways in Erwinia herbicola in relation to pathogenicity on Gypsophila paniculata. Physiol. Mol. Plant Pathol. 39:161-171.

27. Matteson Heidenreich, M. C., Corral-Garcia, M. R., Momol, E. A., and Burr, T. J. 1997. Russet of apple fruit caused by Aureobasidium pullulans and Rhodotorula glutinis. Plant Dis. 81:337-342.

28. Meador, D. B., and Taylor, B. H. 1987. Effect of early season foliar sprays of GA4+7 on russeting and return bloom of "Golden Delicious" apple. Hortscience 22:412-415.

29. Miller, J. H. 1972. Experiments in Molecular Genetics. Cold Spring Harbor Laboratory, Cold Spring Harbor, NY.

30. Morgan, J. V., and Tukey, H. B., Jr. 1964. Characterization of leachate from plant foliage. Plant Physiol. 39:590-593.

31. O'Brien, R. D., and Lindow, S. E. 1989. Effect of plant species and environmental conditions on epiphytic population sizes of Pseudomonas syringae and other bacteria. Phytopathology 79:619-627.

32. Patten, C. L., and Glick, B. R. 1996. Bacterial biosynthesis of indole-3acetic acid. Can. J. Microbiol. 42:207-220.

33. Pilet, P. E., and Saugy, M. 1985. Effects of applied and endogenous IAA on maize root growth. Planta 164:254-258.

34. Rybicka, H. 1981. Tryptophan in root exudate of mock orange and tomato. Acta Physiol. Plant. 3:95-98.

35. Sasser, M. 1990. Technical note 102. Tracking a Strain Using the Microbial Identification System. MIS Inc., Newark, DE.

36. Scott, T. K. 1972. Auxins and roots. Annu. Rev. Plant Physiol. 23:235-258.

37. Spotts, R. A., and Cervantes, L. A. 1995. Copper, oxytetracycline, and streptomycin resistance of Pseudomonas syringae pv. syringae strains from pear orchards in Oregon and Washington. Plant Dis. 79:1132-1135.

38. Walter, T. E. 1966. Russetting and cracking in apples: A review of world literature. Pages 83-95 in: 1966 Annu. Rep. East Malling Station. East Malling Exp. Stn., Maidstone, England.

39. Weibull, J., Ronquist, F., and Brishammar, S. 1990. Free amino acid composition of leaf exudates and phloem sap. Plant Physiol. 92:222226.

40. White, F. F., and Zeigler, S. F. 1991. Cloning of the genes for indoleacetic acid synthesis from Pseudomonas syringae pv. syringae. Mol. PlantMicrobe Interact. 4:207-210.

41. Wilson, M., and Lindow, S. E. 1993. Interactions between the biological control agent Pseudomonas fluorescens A506 and Erwinia amylovora in pear blossoms. Phytopathology 83:117-123.

42. Wilson, M., and Lindow, S. E. 1994. Coexistence among epiphytic bacterial populations mediated through nutritional resource partitioning. Appl. Environ. Microbiol. 60:4468-4477.

43. Xie, H., Pasternak, J. J., and Glick, B. R. 1996. Isolation and characterization of mutants of the plant growth-promoting rhizobacterium Pseudomonas putida GR12-2 that overproduce indoleacetic acid. Curr. Microbiol. 32:67-71. 